Canadian

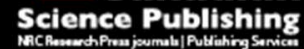

Canadian Journal of Microbiology Revue canadienne de de microbiologie

\title{
RAP-PCR fingerprinting reveals time-dependent expression of development-related genes following differentiation process of Bacillus thuringiensis
}

\begin{tabular}{|r|l|}
\hline Journal: & Canadian Journal of Microbiology \\
\hline Manuscript ID: & cjm-2015-0212.R1 \\
\hline Danuscript Type: & Article \\
\hline Complete List of Authors: & $\begin{array}{l}\text { Huang, Tianpei; Key Laboratory of Biopesticide and Chemical Biology, } \\
\text { Ministry of Education, Fujian Agriculture and Forestry University } \\
\text { Yu, Xiaomin; Key Laboratory of Biopesticide and Chemical Biology, Ministry } \\
\text { of Education, Fujian Agriculture and Forestry University } \\
\text { Gelbič, Ivan; Biology centre CAS, Institute of Entomology, Department of } \\
\text { Biochemistry and Physiology } \\
\text { Guan, Xiong; Key Laboratory of Biopesticide and Chemical Biology, Ministry } \\
\text { of Education, Fujian Agriculture and Forestry University }\end{array}$ \\
\hline Keyword: & $\begin{array}{l}\text { Bacillus thuringiensis, development, RNA-arbitrarily primed PCR, } \\
\text { differentially expressed gene, life cycle }\end{array}$ \\
\hline &
\end{tabular}


1

2

3 4

Canadian Journal of Microbiology, xxx - xxx, 201x

$$
\begin{aligned}
& \text { RAP-PCR fingerprinting reveals time-dependent expression of development-related } \\
& \text { genes following differentiation process of Bacillus thuringiensis }
\end{aligned}
$$

Tianpei Huang ${ }^{\mathrm{a}, \mathrm{b}}$, Xiaomin $\mathrm{Yu}^{\mathrm{a}}$, Ivan Gelbičc** ${ }^{* *}$ Xiong Guan ${ }^{\mathrm{a}, \mathrm{b}^{*}}$

${ }^{\mathrm{a}}$ Key Laboratory of Biopesticide and Chemical Biology, Ministry of Education, Fujian Agriculture and Forestry University, 350002 Fuzhou, Fujian, People's Republic of China ${ }^{b}$ Fujian-Taiwan Joint Center for Ecological Control of Crop Pests, 350002 Fuzhou, Fujian, People's Republic of China

${ }^{c}$ Biological Centre of the Academy of Sciences of the Czech Republic, Institute of Entomology, Branišovská 31, 37005 České Budějovice, Czech Republic 15

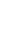

*Correspondent author

Prof. Xiong Guan

Key Laboratory of Biopesticide

and Chemical Biology

Ministry of Education

Fujian Agriculture and Forestry University

350002 Fuzhou, Fujian

People's Republic of China

Telephone: $+86+591+83789259$

Fax: $+86+591+83789259$

E-mail: guanxfafu@126.com
**Co-corresponding author

Assoc. Prof. Ivan Gelbič

Biological Centre AS CR

Institute of Entomology

Branišovská 31

37005 České Budějovice

Czech Republic
Telephone: +420 387772653

Fax: +420 385310

E-mail: gelbic@entu.cas.cz 


\section{Abstract}

Gene expression profiles are important data to reveal gene functions putatively involved in crucial biological processes. RNA arbitrarily primed-polymerase chain reaction (RAP-PCR) and specifically primed reverse transcription PCR (RT-PCR) were combined to screen differentially expressed genes following development of a commercial Bacillus thuringiensis (Bt) subsp. kurstaki strain 8010 (serotype 3a3b). Six differentially expressed transcripts (RAP1 to RAP6) were obtained. The RAP1 encoded a putative triple helix repeat-containing collagen or an exosporium protein $\mathrm{H}$ related to spore pathogenicity. The RAP2 was homologous to a ClpX protease and an ATP-dependent protease La (LonB) likely acted as virulence factors. The RAP3 was homologous to a beta subunit of propionyl-CoA carboxylase (PCC) enzyme (PCCB) required for the development of Myxococcus xanthus. The RAP4 had homology to a quinone oxidoreductase involved in electron transport and ATP formation. The RAP5 showed significant homology to a uridine kinase (UDK) mediated phosphorylation of uridine, azauridine. The RAP6 shared high sequence identity with 3-methyl-2-oxobutanoate-hydroxymethyltransferase (MOHMT) (EC 2.1.2.11) [also known as ketopantoate hydroxymethyltransferase (KPHMT) or PanB] involved in the operation of the tricarboxylic acid cycle. The findings described here would help to elucidate the molecular mechanisms underlying the differentiation process of $\mathrm{Bt}$ and unravel novel pathogenic genes.

Key words: Bacillus thuringiensis, development, RNA-arbitrarily primed PCR, differentially expressed gene, life cycle 


\section{Introduction}

Bacillus thuringiensis (Bt) is a gram-positive, spore-forming bacterium capable of producing a number of toxins including insecticidal endotoxins (delta-endotoxins, ICPs), exotoxins, haemolysins, enterotoxins, chitinase and vegetative insecticidal proteins (VIPs) with toxicity to several insect orders, nematodes, mites and protozoa (Schnepf et al. 1998, $\mathrm{Yu}$ et al. 2007). Since the first report of resistance developing against Bt delta-endotoxins in the field in 1985, insect resistances to $\mathrm{Bt}$ had been discovered both in the laboratory for several insects and in a field population of Plutella xylostella (McGaughey 1985, Liu and Tabashnik 1997). A thorough understanding of Bt pathogenesis at the molecular level is important to develop new strategies for the resistance management.

The life cycle of Bt includes vegetative cell division, spore development (sporulation cycle) and lysis. Its vegetative cell is rod-shaped (2-5 $\mu \mathrm{m}$ long and about 1.0 $\mu \mathrm{m}$ wide) and divides into 2 uniform daughter cells by a division septum. Then the sporulation occurs and a fully sporulated cell of Bt contains ICPs lying along side the endospore. After that, the lysis of the sporulated cell happens, which might be due to nutrition limitation. Herein, ICPs and endospore release from the cell (Ibrahim 2010). The insecticidal activity of Bt was mostly due to ICPs produced during the process of sporulation. Comparative proteomic analysis revealed the metabolic changes of Bt during growth shift, indicating that the cells acquired energy, amino acid precursors and translation-related factors for the ICP synthesis (Gong et al. 2012). Our hypothesis is that Bt genes, whose expression was differentially regulated at different phases (vegetative growth, sporulation and lysis) of the life cycle, could be of special relevance for its pathogenesis.

With the aim of identifying such genes, the RNA arbitrarily primed PCR (RAP-PCR) technique (Welsh et al. 1992), a method closely related to the differential display technique, was employed in this study. The techniques of differential display can be applied to evaluate modifications in transcriptomes according to various conditions in 
72 prokaryotes (Dachet et al. 2010). RAP-PCR technique used random oligonucleotide 73 primers to create a unique cDNA fingerprint for a given microorganism in a particular 74 physiological state, thus providing a powerful tool for assessing differential gene 75 expression in prokaryotes (Benson et al. 2000, Bidle 2003, Bidle and Bartlett 2001, 76 Cabanes et al. 2000, Chia 2001, Dứ and Kolenbrander 2000, Holmstrøm and Gram 2003, 77 Shepard and Gilmore 1999, Smalley et al. 2002, Steger et al. 2002, Fung et al. 2009, 78 Schedel et al. 2011). Real-time or reverse transcription PCR was further used to make 79 sure the cDNA were derived from real differentially expressed genes. Then the cDNA 80 were cloned, sequenced and analyzed. According to the published papers, it is not necessary to do repetition in RAP-PCR. Unlike RAP-PCR, RAPD was often used to 82 obtain the evolution relationship of two or more close species. Thus, the RAPD pattern 83 was usually followed with the construction of phylogenetic trees. To obtain reliable trees, 84 it is necessary to do the repetition of RAPD. RAP-PCR had been successfully used to investigate bacterial development, bacterial virulence genes, microbial responses to 86 environment, and host infection (Benson et al. 2000, Bidle 2003, Bidle and Bartlett 2001, 87 Cabanes et al. 2000, Chia 2001, Dî̉ and Kolenbrander 2000, Holmstrøm and Gram 2003, 88 Shepard and Gilmore 1999, Smalley et al. 2002, Steger et al. 2002, Fung et al. 2009, 89 Schedel et al. 2011). We also have successfully applied RAP-PCR to obtain differentially 90 displayed mRNA related to resistance to Bt subsp. israelensis of Aedes albopictus 91 selected in vitro-activated Cyt1Aa6 (Zhang et al. 2012). Bt subsp. kurstaki 8010 (serotype 92 3a3b) is a commercial strain in China (Guan 1997). In this study, we compared the RNA 93 fingerprints of the bacterial cells during different growth phases and were then able to 94 reveal differentially expressed genes following Bt 8010 development. Our results showed 95 that RAP-PCR is a promising method for obtaining a better understanding of gene 96 expression profiles of Bt during development. 
99

100

101

102

103

104

105

106

107

108

109

110

111

112

113

114

115

116

\section{Materials and Methods}

\section{Bacteria strains and plasmids}

The Bt strain used in this study was Bt subsp. kurstaki 8010 (serotype 3a3b), a commercial strain isolated by our lab (Guan 1997). Escherichia coli JM109 and pMD18-T vector (TaKaRa, Japan) were used for molecular cloning experiments. Luria-Bertani (LB) medium (1\% bactotryptone, $0.5 \%$ yeast extract, $1 \%$ sodium chloride) was used for the growth of bacteria. Bt strain 8010 was cultivated at $30{ }^{\circ} \mathrm{C}$ while E. coli strain was grown at $37^{\circ} \mathrm{C}$.

\section{RNA preparation}

The overnight cultures of Bt strain 8010 were sub-cultured in a $200 \mathrm{ml}$ fresh LB broth with a 1:100 dilution. The growth of cells was monitored by measurements of optical density at $600 \mathrm{~nm}$ periodically with a spectrophotometer (Pharmacia, Sweden) and by observations made under an electron microscope (Olympus U-SPT, Japan). The sub-cultured cells obtained at 5 different time points $(8 \mathrm{~h}, 30 \mathrm{~h}, 39 \mathrm{~h}, 42 \mathrm{~h}$ and $46 \mathrm{~h}$ of sub-culturing) were recovered for RNA extraction, respectively, using the SV Total RNA Isolation System according to the manufacturer's instructions (Promega, USA).

The integrity of the RNA was assessed by electrophoresis of $5 \mu 1$ of each sample through a $1 \%$ agarose- $0.66 \mathrm{M}$ formaldehyde gel in MOPS running buffer [20 mM MOPS (morpholinepropanesulfonic acid, $\mathrm{pH} 7.0$ ), $8 \mathrm{mM}$ sodium acetate, $1 \mathrm{mM}$ EDTA (pH 8.0)] at 3 to $4 \mathrm{~V} / \mathrm{cm}$ [23]. RNA concentration was determined spectrophotometrically by measuring the $\mathrm{OD}_{230}, \mathrm{OD}_{260}$ and $\mathrm{OD}_{280}$ of a 1:500 dilution in DEPC-treated water.

\section{RAP-PCR}

RAP-PCR was performed essentially as previous described (Welsh et al. 1992). Arbitrary 10-mer primers with $50 \%$ of $\mathrm{G}+\mathrm{C}$ content were obtained from Operon 
126 Technologies (USA). First strand synthesis was performed using AMV First Strand 127 cDNA Synthesis Kits (BBI, Canada) according to the manufacturer's instructions. Second

128 strand synthesis was performed in $50 \mu \mathrm{l}$ of reaction mixtures containing $0.7 \mu \mathrm{l}$ of first 129 strand reaction mixtures, $0.5 \mu \mathrm{l}(2.5 \mathrm{U})$ of $\mathrm{Taq}$ polymerase (BBI, Canada), $3 \mathrm{mM} \mathrm{MgCl}$, $1301 \times$ PCR Buffer, $0.5 \mathrm{mM}$ each of the four dNTPs and $0.8 \mu \mathrm{M}$ arbitrary primer. RAP-PCR 131 cycling profile was 40 cycles of $94{ }^{\circ} \mathrm{C}$ for $1 \mathrm{~min}, 37^{\circ} \mathrm{C}$ for $2 \min$ and $72{ }^{\circ} \mathrm{C}$ for $1 \min 30$ $132 \mathrm{sec}$, with a final extension step at extension at $72{ }^{\circ} \mathrm{C}$ for $10 \mathrm{~min}$. Products were resolved 133 on polyacrylamide gels prepared in TBE buffer and were electrophoresed until the xylene 134 cyanol band reached the bottom of the gel. RAP-PCR fingerprints were visualized by 135 silver staining as previously described (Dachet et al. 2010, Sambrook et al. 1989).

\section{Isolation and cloning of RAP-PCR fragments}

After silver staining, individual bands representing differentially expressed products were cut and placed into a microcentrifuge tube containing $50 \mu 1$ of distilled water for

140 overnight elution at $70{ }^{\circ} \mathrm{C}$. A portion of the eluted fragment was applied for the 141 subsequent PCR with the original primer used in RAP-PCR amplification. The PCR 142 products were electrophoresed on a $2 \%$ agarose gel and the bands of the correct size were 143 extracted using the UltraClean ${ }^{\mathrm{TM}} 15$ DNA Purification kit (MO BIO, Canada). Each 144 purified PCR product was ligated into pMD18-T vector (TaKaRa, Japan) by TA cloning, 145 and transformed into E. coli JM109. Transformants were identified by PCR and 146 sequencing.

148 DNA sequencing

149 Cloned cDNAs were sequenced on both strands using $B c a \mathrm{BEST}^{\mathrm{TM}}$ Sequencing 150 Primer RV-M (5'-GAGCGGATAACAATTTCACACAGG-3') and BcaBEST ${ }^{\mathrm{TM}}$ 151 Sequencing Primer M13-47 (5'-CGCCAGGGTTTTCCCAGTCACGAC-3') by ABI 
152 PRISM Model 377 DNA system and sequences obtained were compared to those in the

153 GenBank database by using the BLAST search algorithm to identify similarities to known 154 sequences.

\section{Confirmation of differential gene expression}

Once a candidate differentially expressed fragment was sequenced, a pair of specific primers with 20-23 nucleotides in length (Table 1) were designed based on the sequencing results and used for specifically primed reverse transcription PCR (RT-PCR). RT-PCR was performed under the following conditions-30 cycles of $1 \mathrm{~min}$ at $95{ }^{\circ} \mathrm{C}, 1$ min at $58^{\circ} \mathrm{C}$ and $1 \mathrm{~min}$ at $72{ }^{\circ} \mathrm{C}$, followed by $10 \mathrm{~min}$ at $72{ }^{\circ} \mathrm{C}$. Aliquots of each PCR product were analyzed by electrophoresis in a $2 \%$ agarose gel stained with ethidium bromide. Synthesis of a PCR product of the correct size and expression pattern was considered verified for differential expression of the original RAP-PCR result. 16S rRNA was used as a control gene not affected by the growth kinetics by using the general bacterial primers 27 (5'-ACGGCTACCTTGTTACGACTT-3').

\section{Results}

\section{Growth process of Bt strain 8010}

172 The growth of Bt strain 8010 experienced three typical phases- phase of vegetative 173 growth, sporulation and lysis (data not shown). Briefly, cells grew exponentially during 174 the vegetative phase. At the onset of the stationary phase (at $30 \mathrm{~h}$ of sub-culturing), cells

175 began to sporulate with the endospores forming at one end of the cells and intracellular 176 crystallized inclusions deposited at the other end. Upon mother cell lysis (at $46 \mathrm{~h}$ of 177 sub-culturing), the spores and inclusions were released. 


\section{RAP-PCR analysis}

The five total RNA extracts from the cells of 8010 at $8 \mathrm{~h}, 30 \mathrm{~h}, 39 \mathrm{~h}, 42 \mathrm{~h}$ and $46 \mathrm{~h}$ of sub-culturing were used for RAP-PCR with several arbitrary primers. By RAP-PCR, 19 putative differentially expressed fragments were obtained. However, due to the inability to re-amplify 4 excised fragments, a total of 15 putative differentially expressed gene fragments, designated RAP1 to RAP15, were obtained finally. One example of RNA fingerprinting of RAP-PCR with arbitrary primer A-07 (Operon, USA) was shown in Fig. 1.

The putative differentially expressed fragments, which responded to different growth phases, as represented by changes in bands appearance or disappearance or by differences

189 in bands brightness, could be identified. When a putative differentially expressed 190 fragment from RAP-PCR products was found, it was purified from the gel, re-amplified 191 with the same arbitrary primer and electrophoresed on $2 \%$ agarose gel. The 192 corresponding correct single band, compared to the original RAP-PCR products, was 193 purified and used for the further cloning and sequencing. If several bands of various sizes 194 appeared in the re-amplified product, it suggested that the putative differentially 195 expressed fragment was purified with the nearby fragments in the original RAP-PCR 196 products. In this case, target PCR fragments were subject to several rounds of gel 197 purifications before cloning.

199 Verification of time-dependent expression of differential expressed genes following 200 Bt development by specifically primed RT-PCR

201 Based on sequencing results, 15 specific primer pairs were designed and used for 202 the RT-PCR to confirm differentially expressed genes. Of the 15 candidates from the 203 RAP-PCR, 9 were shown to be false positives by repeating the RT-PCR with respective 204 specific primers and were eliminated from further analysis. The remaining 6 fragments 
(RAP1 to RAP6) were confirmed by RT-PCR to be derived from differentially expressed genes (Fig. 2). For example, the level of the RAP1 transcription was significantly increased during later growth phases, with maximal expression detected at $39 \mathrm{~h}$. Higher RAP2 expressions were seen at 39, 42 and $46 \mathrm{~h}$ compared those at 8 and $30 \mathrm{~h}$. The transcription levels of the RAP3 were higher at 39 and $42 \mathrm{~h}$ compared with those at 30 and $46 \mathrm{~h}$, while there was a dramatic decrease in the expression of the RAP3 at $8 \mathrm{~h}$. Furthermore, the expressions of the RAP4 were stronger at 30, 39 and $42 \mathrm{~h}$ compared with those at 8 and $46 \mathrm{~h}$. The expressions of RAP5 and RAP6 were gradually increased in a time-dependent manner at $30 \mathrm{~h}, 39 \mathrm{~h}, 42 \mathrm{~h}$ and $46 \mathrm{~h}$ compared with that at $8 \mathrm{~h}$. The GenBank accession numbers of RAP 1 to RAP6 were AY646412, AY646414, AY646409, AY646407, AY646406 and AY646410, respectively. We proposed that time-dependent increase of the expressions of the RAP1 to RAP6 may play roles in the development or pathogenesis of $\mathrm{Bt}$.

\section{Characterization of the differentially expressed genes following Bt development}

The differentially expressed genes (RAP1 to RAP6) from Bt 8010 showed high degrees of similarities to Bt proteins possibly involved in sporulation, stress response and pathogenesis (Table 2 and Fig. 3). Of the 6 differentially expressed genes, the RAP1, including BclB C-terminal domain in a number of proteins that have extensive collagen-like triple helix repeat regions, showed 93.6\% identity (294/314 bp) with triple helix repeat-containing collagen / exosporium protein $\mathrm{H}$ from Bt BMB171. The RAP2 showed $97.6 \%$ identity (577/591 bp) with ClpX protease and ATP-dependent protease La (LonB) from the B. cereus group and the close proximity of these two genes indicated they might be co-transcribed from the same operon. Genome sequence search revealed that second ATP- dependent protease La was located adjacent to the above La gene. These 3 genes were highly conserved among the $B$. cereus group, indicating the existence of a putative operon. The others (RAP3 to RAP6) encoded gene products that displayed 
232 varying degrees of similarities to a diverse range of proteins (Table 2), mostly involved in 233 metabolism and energy formation. More specially, RAP3, RAP4, RAP5 and RAP6 234 showed 97.0\% (230/237 bp), 91.4\% (265/290 bp), 99.7\% (295/296 bp) and 98.9\% $235(554 / 560 \mathrm{bp})$ identity with propionyl-CoA carboxylase beta chain (PCCB), quinone 236 oxidoreductase, uridine kinase 237 3-methyl-2-oxobutanoate-hydroxymethyltransferase (also called ketopantoate 238 hydroxymethyltransferase or PanB), respectively, from the B. cereus group.

\section{Discussion}

241 Changes in gene expression can be evaluated by differential display methods, so 242 that effects on bacterial metabolic activity can be estimated by variation in transcription 243 profiles (Dachet et al. 2010). In this study, the RAP-PCR technique has been applied to 244 elucidate the molecular mechanism(s) underlying the differentiation process of Bt and 245 seek for differentially expressed genes.

246 cDNA amplified fragment length polymorphism (cDNA-AFLP) and RAP-PCR were 247 the most frequently used methods for evaluating modifications in transcriptomes. 248 However, cDNA-AFLP requires restriction sites so transcripts without correct sites will 249 not be revealed at all, while RAP-PCR uses acrylamide electrophoresis that lacks the 250 resolution necessary to efficiently separate amplimers (Dachet et al. 2010). Another 251 drawback of both techniques is the high number of false positives generated (Nagel et al. 252 2001). This explained why 9 of the 15 candidates from the RAP-PCR were shown to be 253 false positives.

254 Of the 6 putative pathogenic genes identified from this study, RAP1 encoded a 255 protein showing high sequence identity with triple helix repeat-containing collagen and 256 exosporium protein $\mathrm{H}$ from the $B$. cereus group. The function of Bacillus helix 257 repeat-containing collagen was mostly unknown while the spores of the $B$. cereus group 258 harbored a loose balloon-like exosporium. The particular adherence and hydrophobic 
259

260

261

262

263

264

265

266

267

268

269

270

271

272

273

274

275

276

277

278

279

280

281

282

283

284

285

properties conferred by the exosporium suggested that it might possibly be of significance to spore pathogenicity (Todd et al. 2003). Typically, the ICPs of Bt were deposited against the forespore, developed outside the exosporium, and were separated from spores after sporulation (Zhu et al. 2011). However, in a few strains, such as in Bt subsp. finitimus strains and Bt subsp. oyamensis strain LBIT-113, the ICPs were located between the exosporium and the spore coat and continue to adhere to the spore after mother cell lysis. This phenotype has been previously described as spore-crystal association (SCA) (Zhu et al. 2011). The protein composition of the exosporium was complex. Some may act as structural elements playing a protective role while others may be strongly absorbed, moderating the spore's germination rate (Nagel et al. 2001, Terry et al. 2011). To date, their role in determining spore architecture and spore function is still poorly understood (Terry et al. 2011).

The RAP2 contained part of two genes encoding ATP-dependent clp protease ATP-binding subunit ClpX and ATP-dependent protease La (LonB), respectively. Clp protease was originally identified in vitro as an ATP-dependent protease consisting of two components, the ATPase subunit and the protease (ClpP) subunit (Hwang et al. 1988). ATP-dependent proteins were believed to play roles in differentiation processes and might be virulence factors for bacterial infection in mice (de Crécy-Lagard et al. 1999, Coleman et al. 2009). ClpA and ClpX ATPases are members of a large family of closely related ATPases found in both prokaryotic and eukaryotic cells. They can function as molecular chaperones independent of ClpP. The organization of the Clp protease is complex with its functions and targets varying from one organism to another. In Lactococci lactis, $\mathrm{ClpX}$ is involved in proteolysis of heat damaged proteins and cryoprotection (Skinner and Trempy 2001). Escherichia coli ClpX was an ATP-dependent machine for protein unfolding and translocation and functioned with the ClpP peptidase to degrade target substrates (Stinson et al. 2015). In B. subtilis, Clp is involved in the regulation of competence and sporulation (de Crécy-Lagard et al. 1999, 
Pan and Losick 2003)., B. subtilis DegS-DegU two-component regulatory system was regulated by the ClpXP-Spx regulated proteolysis system (Shiwa et al. 2015). ClpXP

288 protease was responsible for Epsilon antitoxin degradation (Brzozowska and 289 Zielenkiewicz 2014). The canonical E. coli protease La (Lon-Ec), a conserved and much 290 studied protease important for homeostasis by targeting abnormal proteins and unstable 291 regulatory proteins, played a role in host infection (Coleman et al. 2009). Lon protease 292 was conserved from bacteria to humans and regulated cellular processes by degrading 293 different classes of proteins including antitoxins, transcriptional activators, unfolded 294 proteins, and free ribosomal proteins (Osbourne et al. 2014). Sequence analysis revealed 295 that another gene, which also codes for ATP-dependent protease La, was located adjacent 296 to the above protease La gene. These 3 genes were highly conserved among the $B$. cereus 297 group, indicating the existence of a putative operon. Thus, further examination of the 298 existence of such an operon and how it regulates the clp gene expression in Bt will be 299 helpful.

300 Other differentially expressed genes (RAP3, RAP4, RAP5 and RAP6) obtained were 301 mostly involved in metabolism and energy formation. The RAP3 was homologous to 302 PCCB, which was the beta subunit of propionyl-CoA carboxylase (PCC) enzyme (Ugarte 303 et al. 1999). It was required for the development of Myxococcus xanthus and its 304 deficiency can cause propionic academia (Ugarte et al. 1999, Kimura 1997). The PCC 305 was involved in the catabolism of branched chain amino acids, odd-numbered fatty acids, 306 cholesterol, and other metabolites while the PCC in Streptomyces coelicolor can 307 carboxylate different short chain acyl-CoAs (Arabolaza et al. 2010; Chiu et al. 2014).

308 RAP4 had homology to quinone oxidoreductase of B. cereus ATCC 14579 and 309 seemed to be involved in electron transport and ATP formation. Disulphide bond 310 formation catalyzed by thiol-disulphide oxidoreductases (TDORs) was a universally 311 conserved mechanism for stabilizing extracytoplasmic proteins. A TDOR enzyme (BdbD) 312 of B. subtilis had been shown to require a quinone oxidoreductase for activity (Kouwen et 
313

314

315

316

317

318

319

320

321

322

323

324

325

326

al. 2007).

RAP5 showed significant homology to the uridine kinase (UDK) of the B. cereus group, which was a phosphotransferase that mediated phosphorylation of uridine, azauridine and cytidine to produce uridine- azauridine- and cytidine-monophosphate (UMP / aza-UMP / CMP) (Gagyi et al. 2003). The ATP-driven conversion of uridylate monophosphate into uridylate diphosphate was an essential metabolic step in prokaryotes (Meier et al. 2008).

$$
\text { RAP6 shared high sequence identity with }
$$

3-methyl-2-oxobutanoate-hydroxymethyltransferase (MOHMT) (EC 2.1.2.11) [also known as ketopantoate hydroxymethyltransferase (KPHMT) or PanB] from the B. cereus group. This enzyme was indispensable for the synthesis of bacterial pantothenate (vitamin $\mathrm{B}_{5}$ ), which was an essential precursor of coenzyme A (CoA), a key molecule in many metabolic reactions including the synthesis of phospholipids, synthesis and degradation of fatty acids, and the operation of the tricarboxylic acid cycle (Kleinkauf 2000, Villasenor et al. 2011).

If more primers were used, we certainly would obtain more candidate genes for Bt pathogenesis. However, we think it is more urgent to elucidate the precise functions of the 6 putative pathogenic genes (RAP1 to RAP6) by gene knockout and gene complementation. Herein, the genes are currently being disrupted through homologous recombination using pRN5101 thermosensitive vector as previously described (Tran et al. 2011). Based on the comparison of RAP1 gene knock-out mutant with the wide type strain, Exp protein conferred protection to the cells by avoiding premature germination of the cells (unpublished data). Herein, it plays a critical role in the development or pathogenesis of $\mathrm{Bt}$. In conclusion, RAP-PCR was a reliable fingerprinting method to reveal differentially expressed genes following $\mathrm{Bt}$ development.

\section{Acknowledgements}


340 This work was supported by the National Science and Technology Project of 'the

341 Twelfth Five-Year-Plan' for the Rural Development in China (No. 2011AA10A203), the

342 Fujian-Taiwan Joint Center for Ecological Control of Crop Pests (No. Minjiaoke [2013]

343 51), the National Natural Science Foundation of China (No. 31201574), the Leading

344 Talents of Fujian Province College (k8012012a), the Study-abroad Scholarship of Fujian

345 Province (Huang T.), and the Biology Centre CAS, Institute of Entomology (No. RVO:

346 60077344). The authors thank the comments from editors Dr. Germida and Dr. Clarke,

347 and two anonymous reviewers.

\section{$348 \quad$ References}

349 Arabolaza, A., Shillito M.E., Lin T.W., Diacovich L., Melgar, M., Pham, H., Amick, D.,

350 Gramajo, H., and Tsai, S.C. 2010. Crystal structures and mutational analyses of

Benson, N.R., Wong R.M., McClelland M.. 2000. Analysis of the SOS response in

Salmonella enterica serovar typhimurium using RNA fingerprinting by arbitrarily

primed PCR [online]. J. Bacteriol., 182(12), 3490 - 3497. doi:

10.1128/JB.182.12.3490-3497.2000.

Bidle, K.A. 2003. Differential expression of genes influenced by changing salinity using RNA arbitrarily primed PCR in the archaeal halophile Haloferax volcanii [online]. Extremophiles, 7(1): 1-7. doi: 10.1007/s00792-002-0289-0. 
regulated by ToxR in the deep-sea bacterium Photobacterium profundum strain SS9 [online]. J. Bacteriol., 183 (5): 1688-1693. doi: 10.1128/JB.183.5.1688-1693.2001.

Brzozowska, I., and Zielenkiewicz, U. 2014. The ClpXP protease is responsible for the degradation of the epsilon antidote to the zeta toxin of the Streptococcal pSM19035 plasmid [online]. J. Biol. Chem., 289(11): 7514-7523. doi: 10.1074/jbc.M113.519488.

Cabanes, D., Boistard P., and Batut J.. 2000. Identification of Sinorhizobium meliloti genes regulated during symbiosis [online]. J. Bacteriol., 182 doi: 10.1128/JB.182.13.3632-3637.2000.

Chia, J.S., Lee, Y.Y., Huang, P.T., and Chen, J.Y. 2001. Identification of stress-responsive genes in Streptococcus mutans by differential display reverse transcription-PCR [online]. Infect. Immun., 69 (4): 2493-2501. doi: 10.1128/IAI.69.4.2493-2501.2001.

Chiu, Y.H., Liu, Y.N., Liao, W.L., Chang, Y.C., Lin, S.P., Hsu, C.C., Chiu, P.C., Niu, D.M., Wang, C.H., Ke, Y.Y., Chien, Y.H., Hsiao, K.J., and Liu, T.T. 2014. Two frequent mutations associated with the classic form of propionic acidemia in Taiwan [online]. Biochem. Genet. 52(9-10): 415-429. doi: 10.1007/s10528-014-9657-6.

Coleman, J.L., Katona Li Fau - Kuhlow, C., Kuhlow C Fau - Toledo, A., Toledo A Fau Okan, N.A., Okan Na Fau - Tokarz, R., Tokarz R Fau - Benach, J.L., and Benach, J.L. Evidence that two ATP-dependent (Lon) proteases in Borrelia burgdorferi serve different functions [online]. PLoS Pathog. 5(11): e1000676. doi: 
10.1371/journal.ppat.1000676.

383 de Crécy-Lagard, V., Servant-Moisson, P., Viala, J., Grandvalet, C., and Mazodier, P.

384 1999. Alteration of the synthesis of the Clp ATP-dependent protease affects

385 morphological and physiological differentiation in Streptomyces [online]. Mol.

386 Microbiol., 32 (3): 505-517. doi: 10.1046/j.1365-2958.1999.01364.x.

387 Dachet, F., St-Gelais, D., Roy, D., and LaPointe, G. 2010. Transcriptome profiling of

388 lactococcal mixed culture activity in milk by fluorescent RNA arbitrarily

389 primed-PCR [online]. Dairy Sci. Technol., 90 (4): 399-412. doi:

$390 \quad 10.1051 / \mathrm{dst} / 2010020$.

391 Dû, L.D., and Kolenbrander P.E.. 2000. Identification of saliva-regulated genes of 392 Streptococcus gordonii DL1 by differential display using random arbitrarily primed 393 PCR [online]. Infect. Immun., $68 \quad$ (8): 4834-4837. doi: 10.1128/IAI.68.8.4834-4837.2000.

395 Fung Y.W., Chow, H.Y., Law, T.W., Dong, B., and Kwan, H.S. 2009. Development of a 396 low-cost polymerase chain reaction-based method for studying differentially 397 expressed genes in developing rice leaves [online]. J. Integr. Plant. Biol., 51 (6): 398 614-621. doi: 10.1111/j.1744-7909.2008.00801.x.

399 Gagyi, C., Bucurenci N Fau - Sirbu, O., Sirbu O Fau - Labesse, G., Labesse G Fau 400 Ionescu, M., Ionescu M Fau - Ofiteru, A., Ofiteru A Fau - Assairi, L., Assairi L Fau 401 Landais, S., Landais S Fau - Danchin, A., Danchin A Fau - Barzu, O., Barzu O Fau 402 Gilles, A.-M., and Gilles, A.M. 2003. UMP kinase from the Gram-positive bacterium 
403

404

Bacillus subtilis is strongly dependent on GTP for optimal activity [online]. Eur..J. Biochem., 270(15): 3196-3204. doi: 10.1046/j.1432-1033.2003.03702.x.

Gong, Y., Li, M., Xu, D., Wang, H., He, J., Wu, D., Chen, D., Qiu, N., Bao, Q., Sun, M., and Yu, Z. 2012. Comparative proteomic analysis revealed metabolic changes and the translational regulation of Cry protein synthesis in Bacillus thuringiensis [online]. J. Proteomics, 75(4): 1235-1246. doi: 10.1016/j.jprot.2011.10.037.

Guan, X. 1997. Studies on Bacillus thuringiensis 8010. Science Press, Beijing.

Holmstrøm, K., and Gram L. 2003. Elucidation of the Vibrio anguillarum genetic response to the potential fish probiont Pseudomonas fluorescens AH2, using RNA-arbitrarily primed PCR [online]. J. Bacteriol., 185(3): 831-842. doi: 10.1128/JB.185.3.831-842.2003.

Hwang, B.J., Woo, K.M., Goldberg, A.L., and Chung, C.H. 1988. Protease Ti, a new ATP-dependent protease in Escherichia coli, contains protein-activated ATPase and proteolytic functions in distinct subunits [online]. J. Biol. Chem., 263. 8727 - 8734. Available from http://www.jbc.org/content/263/18/8727.full.pdf + html [accessed 10 June 2015].

Ibrahim, M.A., Griko, N., Junker, M., and Bulla, L.A. 2010. Bacillus thuringiensis: a genomics and proteomics perspective [online]. Bioeng. Bugs., 1(1): 31-50. doi: 10.4161/bbug.1.1.10519.

Kimura, Y., Sato R Fau - Mimura, K., Mimura K Fau - Sato, M., and Sato, M. 1997. Propionyl coenzyme A carboxylase is required for development of Myxococcus 
Xanthus [online]. J. Bacteriol., 179, 7098 - 7102. Available from http://jb.asm.org/content/179/22/7098.full.pdf+html [accessed 10 June 2015].

Kleinkauf, H. 2000. The role of 4'-phosphopantetheine in t' biosynthesis of fatty acids, polyketides and peptides. BioFactors, 11(1-2), 91 - 92.

Kouwen T.R., van der Goot, A., Dorenbos, R., Winter, T., Antelmann, H., Plaisier, M.C., Quax, W.J., van Dijl, J.M., and Dubois, J.Y. 2007. Thiol-disulphide oxidoreductase modules in the low-GC Gram-positive bacteria [online]. Mol. Microbiol., 64 (4): 984-999. doi: MMI5707 [pii] 10.1111/j.1365-2958.2007.05707.x.

Liu, Y.B., and Tabashnik, B.E . 1997. Experimental evidence that refuges delay insect adaptation to Bacillus thuringiensis [online]. Proc. R. Soc. Lond. B Biol. Sci., 264 (1381): 605-610. doi: 10.1098/rspb.1997.0086.

McGaughey, W.H. 1985. Insect resistance to the biological insecticide Bacillus thuringiensis [online]. Science, 229(4709): 193-195. doi: 10.1126/science.229.4709.193.

Meier, C., Carter, L.G., Sainsbury, S., Mancini, E.J., Owens, R.J., Stuart, D.I., and Esnouf, R.M. 2008. The crystal structure of UMP kinase from Bacillus anthracis (BA1797) reveals an allosteric nucleotide-binding site [online]. J. Mol. Biol., 381 (5): 1098-1105. doi: 10.1016/j.jmb.2008.06.078.

Nagel, A.C., Fleming, J.T., Sayler, G.S., and Beattie, K.L. 2001. Screening for ribosomal-based false positives following prokaryotic mRNA differential display [online]. Biotechniques, 30 (5): 988-990, 992, 994-986. 
445 Osbourne, D.O., Soo, V.W.C., Konieczny, I., and Wood, T.K. 2014. Polyphosphate, 446 cyclic AMP, guanosine tetraphosphate, and c-di-GMP reduce in vitro Lon activity 447 [online]. Bioengineered, 5(4): 264-268. doi: 10.4161/bioe.29261.

448 Pan, Q., and Losick, R. 2003. Unique degradation signal for ClpCP in Bacillus subtilis 449 [online]. J. Bacteriol., 185 (17): 5275-5278. doi: 10.1128/JB.185.17.5275-5278.2003. 450 Sambrook, J., Fritsch, E.F., and Maniatis, T. 1989. Molecular cloning: a laboratory 451 manual. 2nd ed. Cold Spring Harbor Laboratory Press, N.Y.

452 Schedel, J., Lowin, T., Kujat, R., Judex, M., Scholmerich, J., Nerlich, M., Muller-Ladner, 453 U., and Angele, P. 2011. RAP-PCR fingerprinting reveals time-dependent expression 454 of matrix-related molecules following stem-cell based TGF beta 1-induced 455 chondrocyte development [online]. Int. J. Mol. Med., 27(4): 519-523. doi: 456 10.3892/ijmm.2011.608.

457 Schnepf, E., Crickmore, N., Van Rie, J., Lereclus, D., Baum, J., Feitelson, J., Zeigler, 458 D.R., and Dean, D.H. 1998. Bacillus thuringiensis and its pesticidal crystal proteins 459 [online]. Microbiol. Mol. Biol. Rev., 62(3), 775- 806. Available from 460 http://mmbr.asm.org/content/62/3/775.full.pdf + html [accessed 11 June 2015].

461 Shepard, B.D., and Gilmore,. M.S. 1999. Identification of aerobically and anaerobically 462 induced genes in Enterococcus faecalis by random arbitrarily primed PCR [online].

463 Appl. Environ. Microbiol., 65(4), 1470 - 1407. Available from 464 http://aem.asm.org/content/65/4/1470.full.pdf + html (accessed 11 June 2015)

465 Shiwa, Y., Yoshikawa, H., Tanaka, T., and Ogura, M. 2015. Bacillus subtilis degSU 
operon is regulated by the ClpXP-Spx regulated proteolysis system [online]. J. Biochem., 157(5): 321-330. doi: 10.1093/jb/mvu076.

Skinner, M.M., and Trempy, J.E. 2001. Expression of $c l p X$, an ATPase subunit of the Clp protease, is heat and cold shock inducible in Lactococcus lactis [online]. J. Dairy Sci., 84(8): 1783-1785. doi: 10.3168/jds.S0022-0302(01)74615-2.

Smalley, D., Rocha, E.R., and Smith, C.J. 2002. Aerobic-type ribonucleotide reductase in the anaerobe Bacteroides fragilis [online]. J. Bacteriol., 184 (4): 895-903. doi: 10.1128/jb.184.4.895-903.2002.

Steger, J.L., Vincent, C., Ballard, J.D., and Krumholz, L.R. 2002. Desulfovibrio sp. genes involved in the respiration of sulfate during metabolism of hydrogen and lactate [online]. Appl. Environ. Microbiol., $68 \quad$ (4): 1932-1937. doi: 10.1128/AEM.68.4.1932-1937.2002.

Stinson, B.M., Baytshtok, V., Schmitz, K.R., Baker, T.A., and Sauer, R.T. 2015. Subunit asymmetry and roles of conformational switching in the hexameric AAA plus ring of ClpX [online]. Nat. Struct. Mol. Biol., 22(5): 411-U488. doi: 10.1038/nsmb.3012.

Terry, C., hepherd, A., Radford, D.S., Moir, A., and Bullough, P.A. 2011. YwdL in Bacillus cereus: its role in germination and exosporium structure [online]. PLoS One, 6 8): e23801. doi: 10.1371/journal.pone.0023801PONE-D-11-11360 [pii].

Todd, S.J., Moir, A.J., Johnson, M.J., and Moir, A. 2003. Genes of Bacillus cereus and Bacillus anthracis encoding proteins of the exosporium [online]. J. Bacteriol., 185 (11): 3373-3378. doi: 10.1128/JB.185.11.3373-3378.2003. 
Tran, S.L., Guillemet, E., Ngo-Camus, M., Clybouw, C., Puhar, A., Moris, A., Gohar, M., Lereclus, D., and Ramarao, N. 2011. Haemolysin II is a Bacillus cereus virulence factor that induces apoptosis of macrophages [online]. Cell Microbiol., 13 (1): 92-108. doi: 10.1111/j.1462-5822.2010.01522.x.

Ugarte, M., Perez-Cerda, C., Rodriguez-Pombo, P., Desviat, L.R., Pérez, B., Richard, E., Muro, S., Campeau, E., Ohura, T., and Gravel, R.A.. 1999. Overview of mutations in the PCCA and PCCB genes causing propionic academia [online]. Hum. $\quad 14$ (4): 14 275-282. 10.1002/(sici)1098-1004(199910)14:4<275::aid-humu1>3.0.co;2-n.

Villasenor, T., Brom, S., Davalos, A., Lozano, L., Romero, D., and Los Santos, A.G. 2011. Housekeeping genes essential for pantothenate biosynthesis are plasmid-encoded in Rhizobium etli and Rhizobium leguminosarum [online]. BMC Microbiol., 11, 66. doi: 10.1186/1471-2180-11-66.

Welsh, J., Chada, K., Dalal, S.S., Cheng, R., Ralph, D., and McClelland, M. 1992. Arbitrarily primed PCR fingerprinting of RNA [online]. Nucleic Acids Res., 20 (19): 4965-4970. doi: 10.1093/nar/20.19.4965.

Yu, X., Huang, T., Huang, Z., Powell, C., and Guan, X. 2007. Expression and characterization of inhA gene from Bacillus thuringiensis 8010 [online]. World. J. Microbiol. Biotech., 23 (11): 1621-1625. doi: 10.1007/s11274-007-9408-5.

Zhang, L, Zhang, Q., Huang, E., Li, M., Huang, T., Xu, L., Wu, C., Guan, X., and Gelbič, I. 2012. A differentially displayed mRNA related to resistance to Bacillus 
thuringiensis israelensis of Aedes albopictus selected in vitro-activated Cyt1Aa6 [online]. J. Am. Mosq. Control Assoc., 28(4), 327 - 329. doi: 10.2987/12-6263R.1

Zhu, Y., Shang, H., Zhu, Q., Ji, F., Wang, P., Fu, J., Deng, Y., Xu, C., Ye, W., Zheng, J., Zhu, L., Ruan, L., Peng, D., and Sun, M. 2011. Complete genome sequence of Bacillus thuringiensis serovar finitimus strain YBT-020 [online]. J. Bacteriol., 193 (9): 2379-2380. doi: 10.1128/JB.00267-11.

Zhu, Y., Ji, F., Shang, H., Zhu, Q., Wang, P., Xu, C., Deng, Y., Peng, D., Ruan, L., and Sun, M. 2011.Gene clusters located on two large plasmids determine spore crystal association (SCA) in Bacillus thuringiensis subsp. finitimus strain YBT-020 [online]. PLoS One, 6 (11): e27164. doi: 10.1371/journal.pone.0027164. 
528 Fig. 1 The products of RAP-PCR with arbitrary primer A-07 [Lane 1-5 = the products 529 amplified from the total RNA of Bt 8010 at 8 h, 30 h, 39 h, 42 h, 46 h of sub-culturing, 530 respectively; Lane $\mathrm{M}=100$ bp DNA Ladder Plus. Arrows indicated some differentially 531 expressed fragments. The designation of the corresponding RAP-PCR products was 532 indicated in Table 2]

534 Fig. 2 Reverse transcription PCR (RT-PCR) analysis of 6 differentially expressed gene 535 in Bt 8010 [RT-PCR with respective specific primers was performed using the total RNA 536 extracts from the sub-cultured cells at $8 \mathrm{~h}$ (lane 1), $30 \mathrm{~h}$ (lane 2), $39 \mathrm{~h}$ (lane 3), $42 \mathrm{~h}$ (lane 537 4) and $46 \mathrm{~h}$ (lane 5) as the templates. The RAP1 to RAP6 corresponded to those given in 538 Table 2]

540 Fig. 3 Comparision of 6 RAP genes of Bt 8010 with genomic sequence of Bt BMB171 541 [(A) RAP1. (B) RAP2. (C) RAP3. (D) RAP4. (E) RAP5. (F) RAP6. Gene symbols and 542 gene loci were given above and below each gene, respectively. The RAP gene 543 coordinates were indicated with lines above the genes of Bt BMB171] 


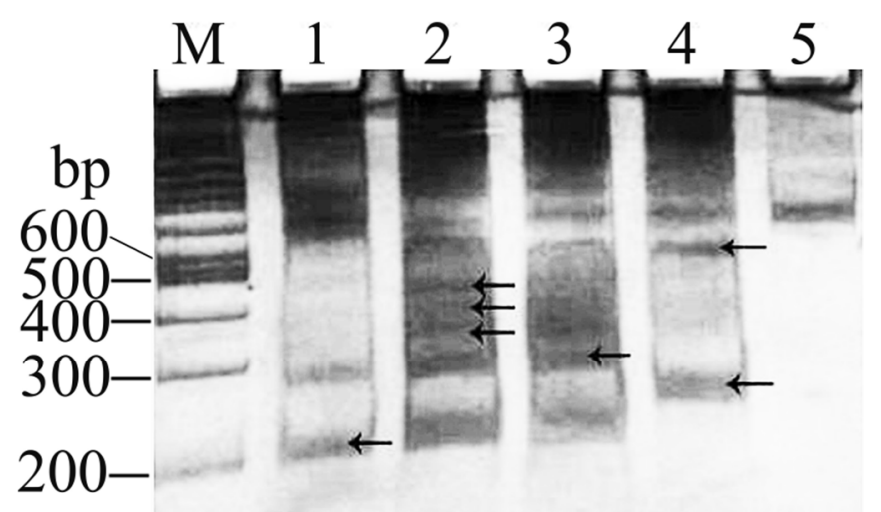

Fig. 1 


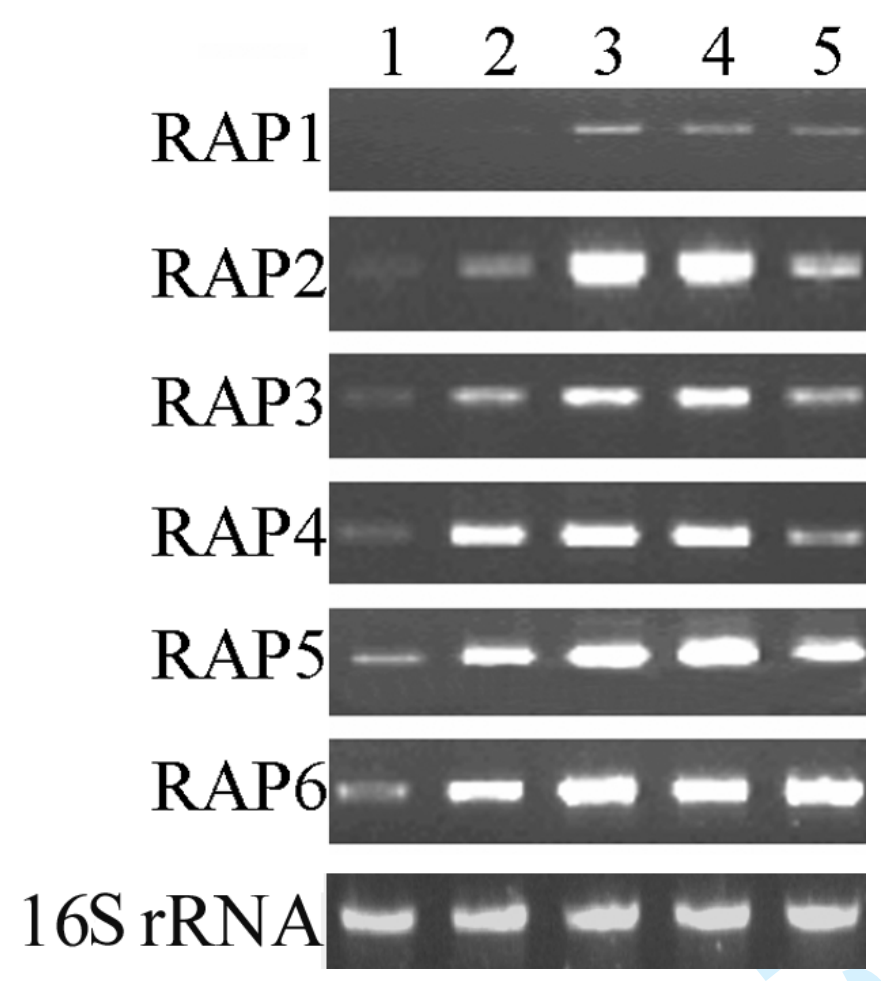

Fig. 2 
A

triple helix repeat-containing collagen triple helix repeat-containing collagen hypothetical protein transcriptional regulator

$$
\text { lys } E
$$

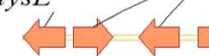
C2138 C2139 C2140 C2141
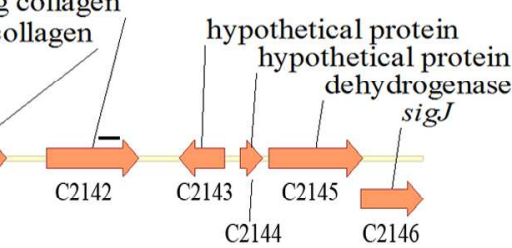

B

engB osmotically inducible protein $\mathrm{C}$ marR C4132

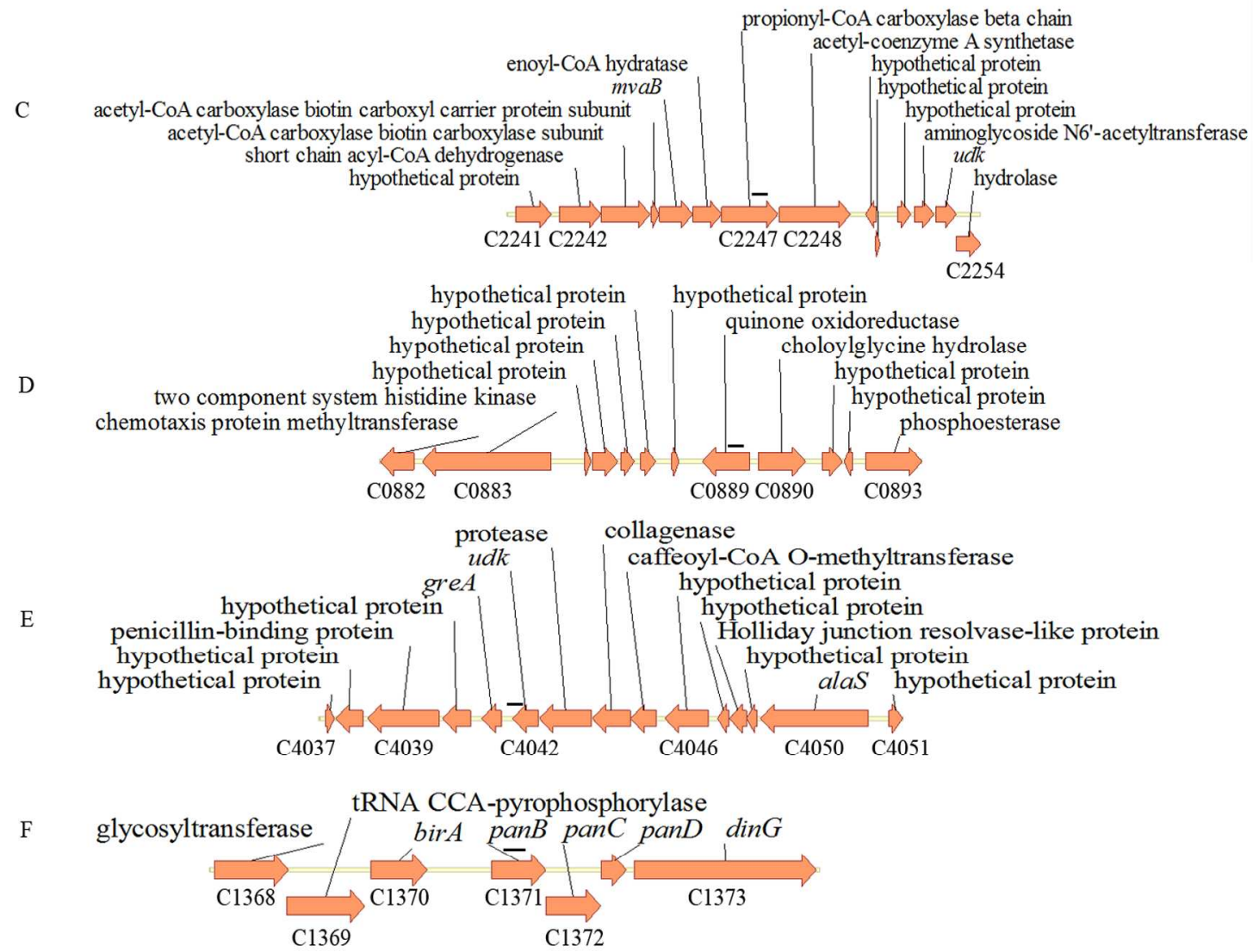

Fig. 3 
Table 1 Specific primers used to confirm the differentially expressed genes

\begin{tabular}{|c|c|c|}
\hline Designation $^{\mathrm{a}}$ & Primers & Sequences \\
\hline \multirow[t]{2}{*}{ RAP1 } & RAP1F & 5'-GCAACAGGTTTAACTGGTGCAAC-3' \\
\hline & RAP1R & 5'- GGAGATAATGCAGCTGTTGC-3' \\
\hline \multirow[t]{2}{*}{ RAP2 } & RAP2F & 5'-CGGGTGCTCGTGGACTTCGTTC-3' \\
\hline & RAP2R & 5'-GTTGCGGATTCGGACCACAAAG-3' \\
\hline \multirow[t]{2}{*}{ RAP3 } & RAP3F & 5'-TCTTCGGTACAGTTGCTTCACC-3' \\
\hline & RAP3R & 5'-GAAGGGTGGCGTATTATTCCAC-3' \\
\hline \multirow[t]{2}{*}{ RAP4 } & RAP4F & 5'-GCCGCTGTGAAATCATCAATGG-3' \\
\hline & RAP4R & 5'-CTTAATTCCCATCACAGGAGCG-3' \\
\hline \multirow[t]{2}{*}{ RAP5 } & RAP5F' & 5'-GACCATTATCAAACGCAAGCGG-3 \\
\hline & RAP5R & 5'-ATGGGGACGAATAAGCCTGTTG-3' \\
\hline \multirow[t]{2}{*}{ RAP6 } & RAP6F & 5'-TACGAAAGCTGTACGCCGCG-3' \\
\hline & RAP6R & 5'- GCGCCAATCCCAATTGTCGG-3' \\
\hline \multirow[t]{2}{*}{ RAP7 } & RAP7F & 5'-CGGGTGCACCAAGTACAGAAG-3' \\
\hline & RAP7R & 5'-TGCAGCGCTATTAGCATTCGTC-3' \\
\hline \multirow[t]{2}{*}{ RAP8 } & RAP8F & 5'-AAACGGGTGACCTCCTGTATTC-3' \\
\hline & RAP8R & 5'-TTGAGCAGCGAACGGTAAGTTC-3' \\
\hline \multirow[t]{2}{*}{ RAP9 } & RAP9F & 5'-GTACCAACACATTTTAGGGC-3' \\
\hline & RAP9R & 5'-GGTGTTGAACTCGGATTTGG-3' \\
\hline \multirow[t]{2}{*}{ RAP10 } & RAP10F & 5'-TTGCGATAAAGTTGCCCGAAGC-3' \\
\hline & RAP10R & 5'-CGGATGTGCTGGATAATGACAC-3' \\
\hline \multirow[t]{2}{*}{ RAP11 } & RAP11F & 5'-TAGTGCTTACTGATCGTCGCAC-3' \\
\hline & RAP11R & 5'-ATCTAACAAGTTATCCCCCCCC-3' \\
\hline \multirow[t]{2}{*}{ RAP12 } & RAP12F & 5'-ACGGACTCGCATTCTATTCC-3' \\
\hline & RAP12R & 5'-TAGACCACCATAAGAACCCC-3' \\
\hline \multirow[t]{2}{*}{ RAP13 } & RAP13F & 5'-GTTGTAGAGACCCATGACAG-3' \\
\hline & RAP13R & 5'-ACGGACTCCATGAGAGAAAC-3' \\
\hline \multirow[t]{2}{*}{ RAP14 } & RAP14F & 5'-CTCGAACTATCTGACTGCAC-3' \\
\hline & RAP14R & 5'-TTGATTGCTGAGGGGATGTC-3' \\
\hline \multirow[t]{2}{*}{ RAP15 } & RAP15F & 5'-GGGTGACGGAGGAGCGAGAC-3' \\
\hline & RAP15R & 5'-AGCGCCATATTTTCCCGGCC-3' \\
\hline
\end{tabular}

${ }^{\mathrm{a}}$ RAP1-RAP6 were the differentially expressed transcripts. 
Table 2 Homology analysis of nucleotide sequences of DNA fragments derived from RAP-PCR

\begin{tabular}{|c|c|c|c|}
\hline Designation $^{a}$ & Band size (bp) & Origin & $\begin{array}{c}\text { Closest homology (accession no.); \% } \\
\text { Similarity }^{\mathrm{b}}\end{array}$ \\
\hline RAP1 & 314 & $39 \mathrm{~h}$ & $\begin{array}{l}\text { Bt BMB171 (NC_014171); 294/310 (95\%); } \\
\text { Triple helix repeat-containing collagen/ } \\
\text { Exosporium protein } \mathrm{H}\end{array}$ \\
\hline RAP2 & 591 & $42 \mathrm{~h}$ & $\begin{array}{l}\text { Bt BMB171 (NC_014171); 573/581 (99\%); } \\
\text { ATP-dependent Clp protease ATP-binding } \\
\text { subunit ClpX, ATP-dependent protease La }\end{array}$ \\
\hline RAP3 & 237 & $42 \mathrm{~h}$ & $\begin{array}{l}\text { Bt BMB171 (NC_014171); 219/228 (96\%); } \\
\text { propionyl-CoA carboxylase beta chain }\end{array}$ \\
\hline RAP4 & 290 & $42 \mathrm{~h}$ & $\begin{array}{l}\text { Bt BMB171 (NC_014171); (262/281) 93\%; } \\
\text { Quinone oxidoreductase }\end{array}$ \\
\hline RAP5 & 296 & $42 \mathrm{~h}$ & $\begin{array}{l}\text { Bt BMB171 (NC_014171);285/286 (99\%); } \\
\text { Uridine kinase }\end{array}$ \\
\hline RAP6 & 560 & $46 \mathrm{~h}$ & $\begin{array}{l}\text { Bt BMB171 (NC_014171); (554/560) 99\%; } \\
\text { 3-methyl-2-oxobutanoate- } \\
\text { hydroxymethyltransferase }\end{array}$ \\
\hline
\end{tabular}

a RAP1-RAP6 were the differentially expressed transcripts. The GenBank accession numbers were AY646412, AY646414, AY646409, AY646407, AY646406 and AY646410, respectively.

${ }^{\mathrm{b}}$ The percent similarity was showed at the nucleotide level. 